\title{
Effects of Combustion Vestibule Configuration on the Competence, Emissions and Combustion attributes of Direct Injection Diesel Prime Mover Powered with Diesel and Corn Oil Methyl Ester (CROME)
}

\author{
M. R. Indudhar ${ }^{1}$, N. R. Banapurmath ${ }^{2 *}$, K. Govinda Rajulu ${ }^{3}$ \\ ${ }^{1}$ Research Scholar, JNTUA, Ananthapuramu, Andhra Pradesh, INDIA \\ ${ }^{2}$ BVB College of Engineering and Technology, KLE Technological University, Hubballi, Karnataka, INDIA \\ ${ }^{3} J N T U A$ College of Engineering, Ananthapuramu, Andhra Pradesh, INDIA
}

*Corresponding Author: nrbanapurmath@gmail.com

Citation: Indudhar, M. R., Banapurmath, N. R. and Govinda Rajulu, K. (2019). Effects of Combustion Vestibule Configuration on the Competence, Emissions and Combustion attributes of Direct Injection Diesel Prime Mover Powered with Diesel and Corn Oil Methyl Ester (CROME). European Journal of Sustainable Development Research, 3(4), em0095. https://doi.org/10.29333/ ejosdr/5831

Published: June 29, 2019

\begin{abstract}
Combustion processes and emissions attributes squarely depend on combustion vestibule volume shapes relative to injector jet directions and cone angles. For injectors with more number of holes, these parameters change and may result in enhanced performance. By this we can make the gases to flow in different patterns compared to conventional engine and can anticipate higher brake thermal efficiency (BTE) and reduced emanations to meet stringent norms. Hence to optimize combustion chamber shapes (CCS) and vary squish, appropriate injection strategies are essential. In this occasion lab probes were conducted on a single cylinder four stroke open or induction swirl diesel engine using corn oil methyl ester (CROME) as fuel. For this variety of CCS were designed and manufactured. Injector with 6 numbers of hole and $0.2 \mathrm{~mm}$ orifice size was used to check its effects on the biodiesel powered engine. The suitable engine available was having Hemispherical Bowl Piston (HBP). To probe the effects of other CCS on the performance of diesel engine, Cylindrical Bowl Piston (CBP), Toroidal Bowl Piston (TBP) and Toroidal Re-entrant Bowl Piston (RBP) vestibule volume shapes were manufactured keeping ratio of compression same. For 100\% replacement of diesel by biodiesel the injection pressures and injection timings tested were in the range of 210 bar to 250 bar and $19^{\circ} \mathrm{bTDC}$ to $27^{\circ} \mathrm{bTDC}$ which are based on our previous research works on other biodiesels. But the performance was maximised for $240 \mathrm{bar}$ and $27^{\circ} \mathrm{bTDC}$ for all CCS which is reported in this paper. Engine variables such as fuel flow rate, brake power, torque, and temperature of exhaust smoke, combustion variables such as rate of heat release (HRR), peak pressure (PP), ignition delay (ID), combustion duration (CD), and exhaust emissions such as smoke opacity, HC, $\mathrm{CO}$, and NOx, were measured. Results obtained with RBP shape and for CROME with 6 number of hole injector concluded in overall ameliorated competence with lesser emission levels of CO, HC and smoke, but NOx was almost same as that of diesel. Also reduced ID, CD and increased PP resulted in decreased burning time loss (BTL) increasing competence. Hence this research work shows that the CROME is also compatible and capable of replacing diesel in a diesel engine efficiently.
\end{abstract}

Keywords: biodiesel, corn oil, CROME, emissions, combustion vestibule volume shapes, squish, swirl, injector, injection time, injector pressure, combustion parameters

\section{INTRODUCTION}

Due to their high part load thermal efficiency diesel powered engines are amply applied for automobile and power plant utilities. But owing to malodours exhaust, vibration levels, noise, particulate matter and smoke, it is essential to use various fuel/engine modifications to enhance diesel engine performance. Depleting petroleum 
reserves forced mankind to invent naturally replenished fuel sources for diesel powered engines which are also available in plenty and sustainable forever. While using these alternate energy sources care has to be taken to control pollution not to affect delicate environmental balance. Hence research has to be carried out to efficiently harness energy sources and meet stringent emission regulations which are reset every year. Real Driving Emission (RDE) will be introduced that will measure the emissions in real-world situations and just not under test conditions. Hence it is time to implement new methods and modifications that ameliorate the thermal efficiency of diesel engine. Naturally replenished fuel sources are inexhaustible and are eco-friendly also (Goldemberg et al., 2004). Biodiesel liquids peculiarly more precise in place of diesel applications as they have complying thermal properties. Even though biodiesel is used since 1893, we have to overcome certain problems before it fully replaces petroleum diesel. The literature survey shows that $100 \%$ biodiesel use lead to deposits on various components of engine, creating problems and decreasing performance. Hence, durability tests were carried out over 200 hours to compare the impacts of B50 (50\% biodiesel and 50\% diesel by volume) and Indonesian biodiesel fuel (IBF: diesel containing $10 \%$ biodiesel of palm oil) on engine. Relatively more amounts of deposits were produced by B50 on various engine parts by which ring sticking risk also increased (Taufiq Suryantoro et al., 2016). Similar results are shown by other researchers also (Arifin and Arai, 2009; Caceres et al., 2003).

Changchun Xu et al. (2018) investigated the combustion attributes of a DICI engine by using three geometric piston bowls to compare eddy viscosity and turbulent flow energy. They are flat bottom, double circle and single circle so that combustion attributes can be improved reducing emissions. By simulation it was found that a double circular geometry piston has the highest kinetic turbulent energy (KTE) which resulted in two peak heat releases, one is main peak during uncontrolled combustion and the other peak occurs during the diffusion combustion stage. They found that the shape of the double round bottom is more effective in squeezing biofuel-air mixture by better vortexing than the other shapes in promoting the rate of mixing and hence improve combustion process.

Channappagoudra et al. (2018) modified hemispherical piston bowl geometry (HPBG) of existing diesel engine into toroids piston bowl (TPB) to measure the performance of scum oil of dairy and its B20 biodiesel and realised that optimizing operating conditions as well as combustion geometry is highly essential to achieve a better performance. The experiments resulted in increased BTE and HRR by $5.5 \%$ and $17.24 \%$, respectively, BSFC, HC and CO emissions were decreased by $8.75 \%, 15 \%$ and $14.47 \%$, respectively using 5 holes injector. Such improvements using the TPB may be due to improved fuel atomization thus reducing fuel droplet size, higher cylinder temperature, enhanced swirl-squish and kinetic turbulent energy during burning process.

Ravichandran et al. (2016) studied the effect of hemispherical bowl piston and toroidal shaped bowl piston in a CI engine fuelled with 100\% corn oil methyl ester using 3 holes injector available in existing kirloskar engine and got BTE of $24 \%$ and $26 \%$ directly measured from their graph. Their other results are discussed in results and discussions.

The values of performance parameter BTE, emissions smoke, CO, UBHC, NOx, and combustion variables ID, CD, PP and HRR mainly depend on shape of combustion chamber geometry. The summary of this work shows that designing proper combustion chamber geometry, adoptability of alternative fuels can be improved as reported by Praveena et al. (2017) and Praveena et al. (2018).

According to Alireza Lotfi and Hassan Ghassemi (2017), one of the important issues the researchers are considering today is the study of combustion vestibule for direct injection or open induction swirl chamber and divided or indirect injection combustion chamber. They studied piston design in two pieces - basic piston with four crown inserts having squish areas of $40 \%, 35 \%, 30 \%$ and $25 \%$, out of them $30 \%$ piston bowl improved combustion performance and reduced emissions. Out of square, Toroidal, shallow depth, cylindrical, hemispherical and Toroidal Re-entrant combustion chambers, the TRCC model was more favourable for factors such as turbulence, kinetic energy and rotation in the compaction stage and the quality of movement of air which was thus deceased in the order respectively, i.e, TRCC,TCC, SCC, CCC, HCC and SqCC. They used CFD code, bur AVL FIRE and KIVA-CHEMKIN as simulating software for the performance and analysis of combustion.

Nagarsheth and Gossay (2016) fabricated two different types of TBC (thermal barrier coating) combustion chambers to analyze the diesel cycle. Their diesel motor was made using TBC ceramic materials which is concept of regeneration. Thus it acts as an adiabatic engine which reduces heat loss thereby improving combustion and reducing exhaust emissions. The engine components such as upper surface of piston, engine head cylinder, liners and valves, were completely coated with $\mathrm{TBC}$ materials such as $\mathrm{MgZrO}_{3}\left(\mathrm{MgZrO}_{3}\right.$ magnesium zirconium oxides) and YSZ (Yttria stabilized Zirconia), in both cases one more TBC coating band NiCrAlY (Nickel chromium aluminium yttria) was used to provide stability and mechanical strength. The analysis of combustion periods was carried out and various results such as cylinder pressure, pressure diagrams, mass fraction and heat emission were recorded. Out of two TBC materials $\mathrm{MgZrO} 3$ was better which gave complete combustion with higher HRR. Due to coating compression pressure was increased by 10.50 percent with more work output and increased thermal efficiency. 
As per Ramesh Bapu et al. (2015), the ID range for Calophyllum Inophyllum Methyl Ester (CIME) in Modified HCC (MHCC) for biodiesel blend B20 is almost same as that of diesel in HCC and it reduces with the increase in load and higher cylinder temperature. But they also added that due to higher specific heats the exhaust gases were absorbing more heat thereby reducing peak pressure and high temperature attained. Hence the peak pressure increase by $4.8 \%$ for MHCC than in HCC for diesel due to more amount of fuel burning in the premixed combustion stage due to change in ID duration.

Waste cooking oil, animal fats and algae (micro algae and macro algae) can also be used for producing biodiesels. Biodiesels derived from a number of vegetable oils like honne (Calophyllum Inophyllum Linn), honge (karanja or pongamia pinnata), corn, rubber seed (Heaviabresiliensis), palm, rape seed, jatropha (Ratanjyot), neem seed, Marotti oil ( Hydnocarpus Wigtiana or Chaulmogric Acid), mahua oil and cotton seed oil (Gossipium Hirsutum) are used as alternative fuel sources in diesel prime movers (Banapurmath et al., 2009; Fangsuwannarak et al., 2016; Gopinath and Suresh, 2015; Nalgundwar et al., 2016; Onga et al., 2011; Rajan and senthikumar, 2010; Ragit et al., 2010). Competence of the engine reduced slightly by increased emissions and inferior combustion modes as put forth for biodiesels operation in engines by several researchers (Banapurmath and Tewari, 2009; Gopinath and Suresh, 2015; Nalgundwar et al., 2016; Nwafor, 2000, 2003; Rajan and senthikumar, 2010; Ramadhas et al., 2005; Ravindranatha and Balachandra, 2009; Recai et al., 2011; Rehman and Ghadge, 2004), but ensuring that we can run engines even when fossil fuels exhaust. Jatadhara et al. (2018) showed that oil from waste plastic can be a source for biodiesel and effectively used in a diesel engine whose BTE very close to that of diesel but increased oxides of nitrogen, carbon dioxide at injection timing of $23^{\circ} \mathrm{bTDC}$. They also demonstrated that oxides of nitrogen, carbon monoxide and unburnt hydrocarbons reduced for retarded injection timing of $14^{\circ} \mathrm{bTDC}$. Also important point to be noted is that biodiesel is synthesised from material which is non-biodegradable and environmentally malicious. Gopinath et al. (2015) used diesel and corn biodiesel oil blends and reported that a blend of $80 \%$ diesel $+20 \%$ biodiesel gave optimum performance. Onga et al. (2011) studied comparison of performances of Jatropha curcas, Calophyllum inophyllum linn, palm oil biodiesels used in same engine and reported that all oils performed well but Calophyllum inophyllum linn oil was better than others with lower emissions. In the literature, variation of parameters on the competence and exhaust of a diesel prime mover utilising biodiesel and blending with diesel were presented. It was concluded that piston bowl shapes have profound outcome on competence of diesel prime mover (Gajendra Babu, 2007; Godiganur et al., 2009; Muralidharan and Vasudevan, 2011; Nwafor, 2003; Sakthisaravanasenthil, et al., 2017). Changes in timings of fuel injection change the position of the piston when the injection takes place thereby changing the duration of injection relative to TDC and hence cylinder pressure and temperature. There was appreciable reduction in biodiesel NOx and also diesel NOx as per Hountalas et al. (2001), when fuel injections retarded. When injection timings were retarded and injection pressures increased cylinder temperatures and pressures gradually decreased (Bari et al., 2002; Rosli et al., 2008). Experiments on Kruczynski et al. (2013), reported good engine competence testing camelina sativa oil and stressed the impetus needed to change fuel system calibration parameters that utilise alternate fuels. Alternate oil combustion was much contrasting to that of diesel owing to its high percentage of Linolenic acid. Rice bran oil showed that supercharging can ameliorate better air fuel mixing, reducing HC and smoke and emit slightly increased NOx. Similarly (Banapurmath and Tewari, 2009; Chaichan, 2015; Forson and Odur, 2004; Ravichandran et al., 2016; Recai et al., 2011; Yaliwal et al., 2011) studied biodiesel fuelled diesel engines successfully. The quality of combustion not only depends on properties of alternate fuels used but also on design of combustion vestibule volume shapes. Both simulation-modelling and experimental inquest on the use of various combustion vestibule shapes was carried out by many researchers in this direction (Alireza Lotfi and Hassan Ghassemi, 2017; Bawankar and Gupta et al., 2016; Jaichander and Annamalai, 2012; Matsumuto et al., 1977; Prasad et al., 2011; Ravichandran and Rajan, 2016). The swirl and turbulence were intensified in re-entry combustion vestibule when contrasted to cylindrical type which leads to meliorated burning thus forming more NOx emissions and less soot and $\mathrm{HC}$ emissions (Bharathi and Prasanthi, 2011; Jaichander and Annamalai, 2012, 2013; Montajir et al., 2000). Entrainment of air and hence meliorated mixing rates are witnessed with enhanced swirl and injector pressure (Bharathi and Prasanthi, 2011; McCracken and Abraham, 2001). Prasad et al. (2011) carried out inquest on air motion in various combustion vestibule volume shapes and optimised geometry by computational fluid dynamics for high turbulent kinetic energy at top dead centre (TDC) position. Toroidal combustion vestibule with deep toroids and a shallow re-entrance and the spray aiming towards the entrance of bowl decreased the NOx emissions to the maximum when contrasted with baseline hemispherical bowl vestibule (Jaichander and Annamalai, 2012; Matsumoto et al., 1977). Also they reported reduced ID, higher PP for B20 increased BTE reduced emissions of particulates, CO and HC. Similarly (Bari et al., 2002; Jaichander and Annamalai, 2003, 2012; Montajir et al., 2000) studied that combustion vestibule geometries influence intermixing of air and biodiesel fuels which increment diesel engine performance, successfully. The interaction of fuel with air after injection into the combustion vestibule volume is important. Hence nozzle with 6 holes was used in this study which may impress atomization, entrainment and mixing process of fuel with air. Faster-cleaner combustion may be realised with competent changes in the in-cylinder burning 
zone. The competence and emissions attributes of diesel prime movers are largely impressed by the way fuel is sprayed, atomized and entrained into hot swirling air which depends on injector design and hence flow patterns. Many researchers have explored outcomes of kinetic features like spray flows, wall wetting and dribbling on burning rate and emissions (Bari et al., 2002; Changchun Xu et al., 2018; Mulemani et al., 2004). Experimental probes to throw more light on injection strategies and fuel jets behaviour in induction swirl is highlighted in literature (Alireza Lotfi and Hassan Ghassemi, 2017; Benajes et al., 2004; Hans et al., 2002; Pyari et al., 2008).

Objectives of this research work: The main objective of this work is to enhance biodiesel performance by taking it very close to that of diesel in diesel engine by varying operating conditions. As per the detailed literature survey it follows that different CCS, different materials and strategies were used but no one has used a 6 holes injector for different CCS for use of biodiesel CROME in diesel engine. Also it is clear that no one has tried 100\% replacement of diesel using 6 holes injector. Hence it is planned to use 100\% CROME in this work. As the viscosity of CROME is more than diesel, high injection pressures are to be used to improve spray formation. An advanced injection timings are to be used to provide more time for CROME for proper mixture formation with air anticipating improved combustion characteristics. Thus experiments were conducted on four stroke open or induction swirl diesel prime mover utilising CROME with diverse combustion vestibule volume shapes fabricated and explored in this inquest to improve competence and decrease emissions.

$\begin{array}{ll}\text { Nomenclature } \\ \text { BTE } & \text { Brake thermal efficiency } \\ \text { CR } & \text { Compression ratio } \\ \text { CROME Corn oil methyl ester } \\ \text { BDF } & \text { Biodiesel fuel } \\ \text { DICI } & \text { Direct injection compression ignition } \\ \text { IT } & \text { Injection timing } \\ \text { IOP } & \text { Injector opening pressure } \\ \text { TDC } & \text { Top dead centre } \\ \text { bTDC } & \text { Before top dead centre } \\ \text { aTDC } & \text { After top dead centre } \\ \text { CCS } & \text { Combustion chamber shapes } \\ \text { HBP } & \text { Hemispherical bowl piston } \\ \text { CBP } & \text { Cylindrical bowl piston } \\ \text { TBP } & \text { Toroidal bowl piston } \\ \text { RBP } & \text { Reentrant Toroidal bowl piston } \\ \text { BSFC } & \text { Brake specific fuel consumption } \\ \text { ID } & \text { Ignition delay } \\ \text { CD } & \text { Combustion duration } \\ \text { NOx } & \text { Oxides of nitrogen } \\ \text { HC } & \text { Hydrocarbon } \\ \text { CO } & \text { Carbon monoxide } \\ \text { SI } & \text { Spark ignition } \\ \text { CA } & \text { Crank angle } \\ \text { PP } & \text { Peak pressure } \\ \text { HRR } & \text { Heat release rate } \\ \text { BTL } & \text { Burning time loss } \\ & \end{array}$

\section{CHARACTERISATION OF CORN OIL (MAIZE OIL), PREPARING CORN OIL BIODIESEL}

Corn oil is obtained from the corn germ (maize) which is used for edible and non-edible purposes. It is commonly not used for cooking. In this inquest Diesel and Corn oil methyl ester (CROME) were tested and contrasted for competence. CROME was synthesised by trans-esterification process, there by triglycerides of raw corn oil were transformed into their monoesters by reacting with methanol. Initially $500 \mathrm{ml}$ of corn (maize) oil was taken in a round bottom flask and heated at about $65^{\circ} \mathrm{C}$ for $10 \mathrm{~min}$ to remove moisture content present in it by using heating arrangement as shown in Figure 2. Then $110 \mathrm{ml}$ of methanol was taken in separate beaker and $5 \mathrm{gm}$ of $\mathrm{NaOH}$ pellets dissolved in it completely. Later this solution transferred to round bottom flask and simultaneously stirring and heating process continued for next one hour. A combined hot-plate magnetic-stirrer device is used for this purpose which has two knobs to independently control stirring and heating rates. A magnetic stirrer uses a magnetic field to spin a stirring bar quickly which is immersed in liquid. A set of stationary electromagnets are fixed beneath the vessel which create rotating field. The hot plate is usual electrical heater. A 


\section{$\mathrm{CH}_{2} \mathrm{OOC}-\mathrm{R1}$ \\ CHOOC-R $2+3 \mathrm{CH}_{3}$ d $\mathbf{H}_{2} \mathbf{O O C}-\mathbf{R 3}$}

Triglycerides Methanol

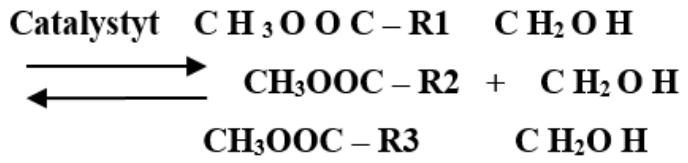

Methyl-Esters Glycerol

Figure 1. Transesterification reactions

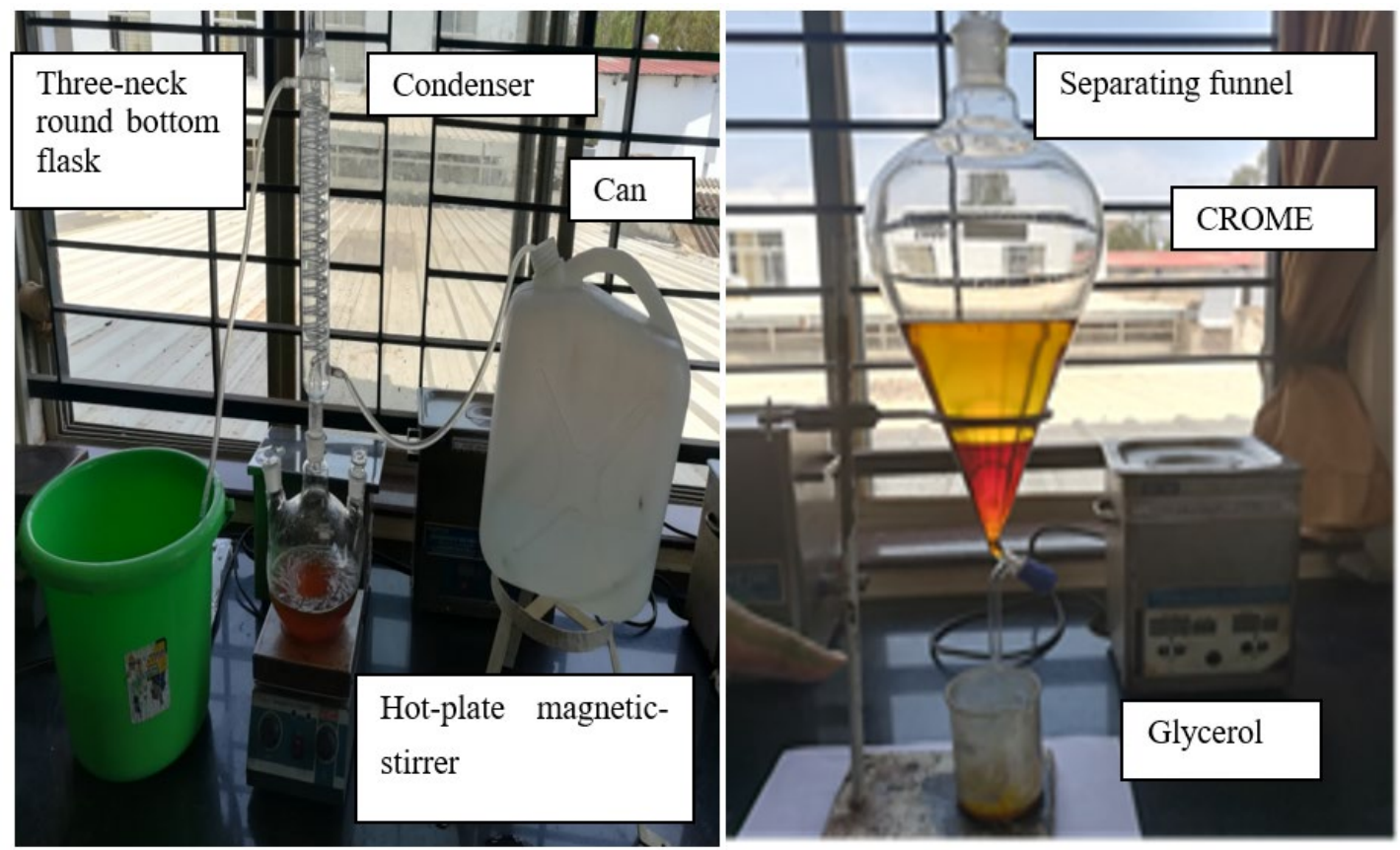

Figure 2. Biodiesel production by transesterification using a combined hot-plate magnetic-stirrer device set-up

Table 1. Contribution of fatty acids of corn oil samples and its chemical structure

\begin{tabular}{|c|c|c|c|c|c|c|c|c|}
\hline $\begin{array}{l}\text { S1. } \\
\text { No. }\end{array}$ & Composition & $\begin{array}{c}\text { Percentag } \\
\text { Fatty oils } \\
\text { Corn oil } \\
\end{array}$ & Chemical name & $\begin{array}{l}\text { No of } \\
\text { bonds }\end{array}$ & Structure & $\begin{array}{l}\text { Saturated or } \\
\text { Unsaturated }\end{array}$ & $\begin{array}{l}\text { Chemical } \\
\text { formula }\end{array}$ & $\begin{array}{l}\text { Mol. } \\
\text { wts. }\end{array}$ \\
\hline 1 & PALMITIC & 16 & HEXADECANOIC & -- & 16.0 & Saturated & $\mathrm{C}_{16} \mathrm{H}_{32} \mathrm{O}_{2}$ & 256 \\
\hline 2 & STEARIC & 18 & OCTADECANOIC & -- & 18.0 & Saturated & $\mathrm{C}_{18} \mathrm{H}_{36} \mathrm{O}_{2}$ & 284 \\
\hline 3 & OLEIC & 18.1 & $\begin{array}{l}\text { CIS-9- } \\
\text { OCTADECANOIC }\end{array}$ & Single & 18.1 & Unsaturated & $\mathrm{C}_{18} \mathrm{H}_{34} \mathrm{O}_{2}$ & 282 \\
\hline 4 & LINOLEIC & 18.2 & $\begin{array}{l}\text { CIS-9,CIS-12- } \\
\text { OCTADECANOIC }\end{array}$ & Double & 18.2 & Unsaturated & $\mathrm{C}_{18} \mathrm{H}_{32} \mathrm{O}_{2}$ & 280 \\
\hline 5 & LINOLENIC & 18.3 & $\begin{array}{l}\text { CIS-9,CIS-12,CIS- } \\
\text { 15OCTADECANOIC }\end{array}$ & Triple & 18.3 & Unsaturated & $\mathrm{C}_{18} \mathrm{H}_{30} \mathrm{O}_{2}$ & 278 \\
\hline 6 & ARACHIDIC & 2.36 & ETCOSANOIC & -- & 20.0 & Saturated & $\mathrm{C}_{20} \mathrm{H}_{40} \mathrm{O}_{2}$ & 312 \\
\hline 7 & LIGNOCERIC & 1.53 & TETRACOSANOIC & -- & 24.0 & Unsaturated & $\mathrm{C}_{24} \mathrm{H}_{48} \mathrm{O}_{2}$ & 368 \\
\hline 8 & BEHENIC & 5.82 & DOCOSANOIC & -- & 22.0 & Unsaturated & $\mathrm{C}_{22} \mathrm{H}_{44} \mathrm{O}_{2}$ & 340 \\
\hline
\end{tabular}

condensing arrangement is provided to condense the evaporated mixture of methanol and corn oil as shown in Figure 2 by continuous flow of cold water through condenser helical tube from a can. The cold water condenses vapours which flow down into flask as liquid. Later on this solution transferred into a separating funnel where the pure corn coil gets separated from the glycerol after leaving it for one day. The glycerol is collected at the bottom and pure corn oil at top which can be separated easily. The pure corn oil obtained must be cleaned with warm water for three times to remove any residual oil in it.

The corn oil is composed of many fatty acids. Their percentage contribution, chemical formula, chemical structure and their molecular weights are shown in Table 1. According to ASTM standards, experimentally thermal properties of CROME were found and are given in Table 2. 
Indudhar et al. / Effects of Combustion Vestibule Configuration on the Competence, Emissions and Combustion ...

Table 2. Properties of corn oil, CROME and diesel

\begin{tabular}{|c|c|c|c|c|c|}
\hline $\begin{array}{c}\text { Sl. } \\
\text { No.o.N }\end{array}$ & Properties of oils & Diesel & Raw Corn oil & CROME & ASTM Norms \\
\hline 1 & $\begin{array}{l}\text { Kinematic Viscosity (Centi Stokes at } \\
40^{\circ} \mathrm{C} \text { ) }\end{array}$ & 3.5 & 35 & $4.18-4.52$ & ASTMD445 \\
\hline 2 & Flash Point $\left({ }^{\circ} \mathrm{C}\right)$ & 56 & 176 & 160 & ASTM D93 \\
\hline 3 & $\begin{array}{l}\text { Calorific Value } \\
(\mathrm{kJ} / \mathrm{kg})\end{array}$ & 45,000 & 36,300 & 38,480 & ASTM D5865 \\
\hline 4 & Mass Density $\left(\mathrm{Kg} / \mathrm{m}^{3}\right.$ at $\left.15^{\circ} \mathrm{C}\right)$ & 830 & 896 & 860 & ASTM D4052 \\
\hline 5 & Cetane Number & $45-55$ & 40 & 65 & ASTM D613 \\
\hline 6 & Cloud Point $\left({ }^{\circ} \mathrm{C}\right)$ & 15 & 13 & ---- & ASTM D2500 \\
\hline 7 & Pour Point $\left({ }^{\circ} \mathrm{C}\right)$ & 1 & -2 to -5 & ---- & ---- \\
\hline 8 & Carbon Residue (\%) & 0.1 & 0.66 & ---- & ASTM D4530 \\
\hline 9 & Oil type & Fossil fuel & Non-edible & Non edible & ----- \\
\hline 10 & Auto ignition temperature $\left({ }^{\circ} \mathrm{C}\right)$ & 260 & ------ & ------ & $\begin{array}{ll}---- \\
\end{array}$ \\
\hline 11 & Sulphur Content & High & No & No & $\begin{array}{ll}---- \\
\end{array}$ \\
\hline
\end{tabular}

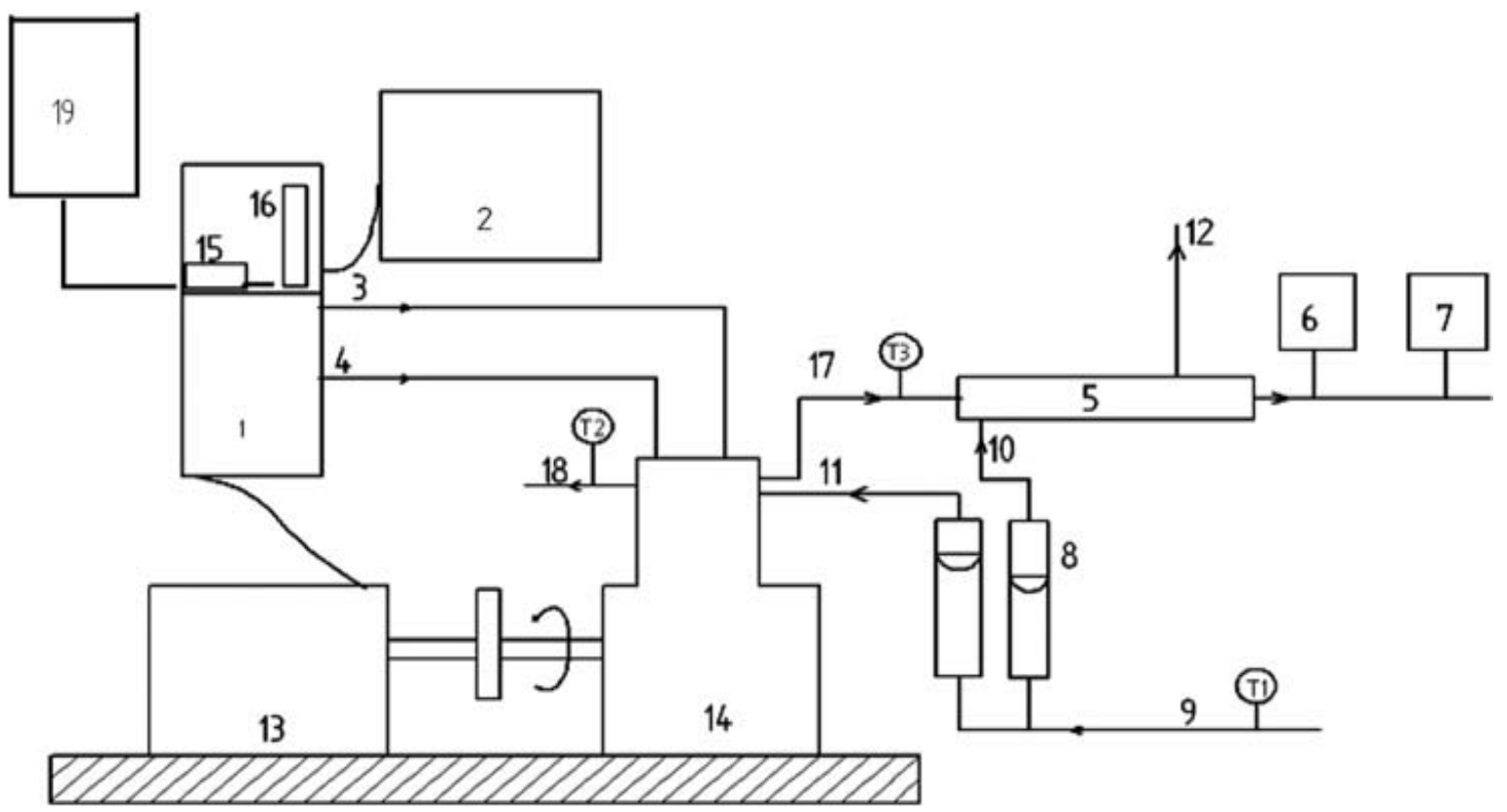

Figure 3. Line diagram of equipment setup

1. control panel, 2. computer system, 3. diesel flow lines, 4. air flow line, 5. calorimeter, 6. exhaust gas analyzer, 7. smoke meter, 8. rotameters, 9, 11. inlet water temperature, 10. calorimeter inlet water temperature, 12. calorimeter outlet water temperature, 13. dynamometer, 14. CI engine, 15. speed measurement, 16. burette for fuel measurements, 17. exhaust gas outlet, 18. outlet water temperature, 19. fuel tank, T1. inlet water temperature, T2. outlet water temperature, T3. exhaust gas temperature

\section{EXPERIMENTAL SETUP}

Diesel engine set up has data acquisition system with software Enginesoft as shown in Figure 3 and engine specifications for the probe are shown in Table 3. Thorough experimental work conducted on constant speed (1500 RPM) Kirloskar TV1 type single cylinder diesel prime mover fitted with conventional helix bypass pump facility powered with diesel and CROME. Loading of the engine is by eddy current type dynamometer (model AG-10). Light extinction type Hartridge smoke opacity meter and five gas analyzer (DELTA 1600S) are utilised to measure emission characters at thermodynamic equilibrium state. A piezoelectric pressure sensor (Model: PCB Piezotronics, HSM 111A22 with resolution: $0.145 \mathrm{mV} / \mathrm{kPa}$ ) is mounted with the cylinder head surface to measure the cylinder gas pressure. Diverse combustion vestibule volume shapes of Hemispherical (HBP), Cylindrical (CBP), Toroidal (TBP) and Toroidal Re-entrant (RBP) were used as shown in Figure 4 (a), (b), (c) and (d). To inquest the outcome of number of holes, injector having 6 holes of $0.2 \mathrm{~mm}$ size was utilised. The outcomes of biodiesel and diesel operations were contrasted and concluded. 
Table 3. Diesel engine specifications

\begin{tabular}{cll}
\hline S1. No. & Parameters & Specifications \\
\hline 1 & Engine type & TV1 ( Kirlosker make) \\
\hline 2 & Software used & Engine soft \\
\hline 3 & Injector operating pressure & 200 to 225 bar \\
\hline 4 & Static injection time & 23obTDC \\
\hline 5 & Governor type & Centrifugal type Mechanical \\
\hline 6 & No of cylinders & Single cylinder \\
\hline 7 & No of strokes & 4 stroke \\
\hline 8 & Fuel oil & High Speed Diesel \\
\hline 9 & Rated power & $5.2 \mathrm{~kW}$ at $1500 \mathrm{rpm}$ \\
\hline 10 & Cylinder diameter (Bore) & 0.0875 meter \\
\hline 11 & Stroke length & 0.11 meter \\
\hline 12 & Ratio of compression & $17.5: 1$ \\
\hline
\end{tabular}

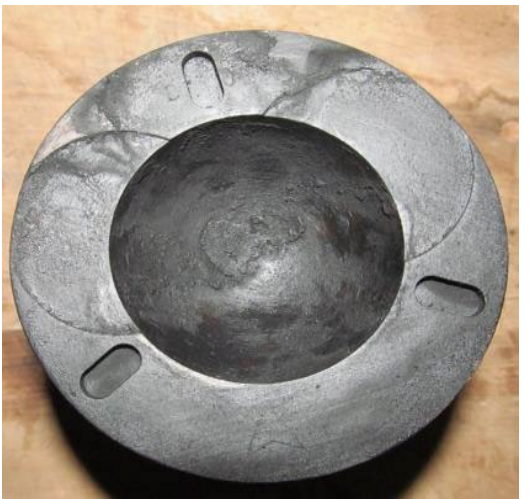

(a) Hemispherical type

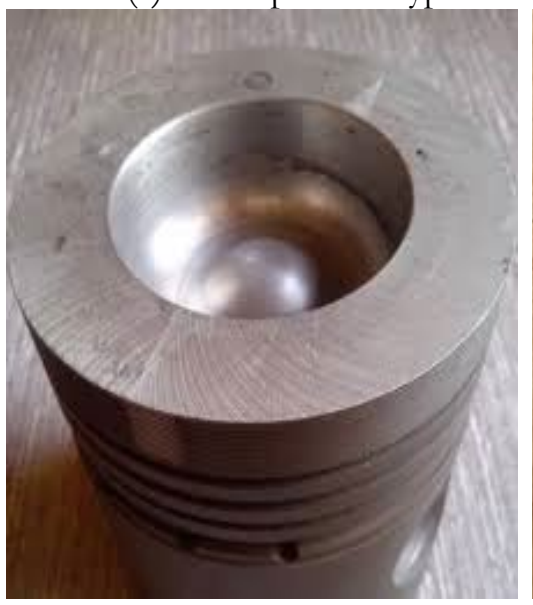

(c) Toroidal type

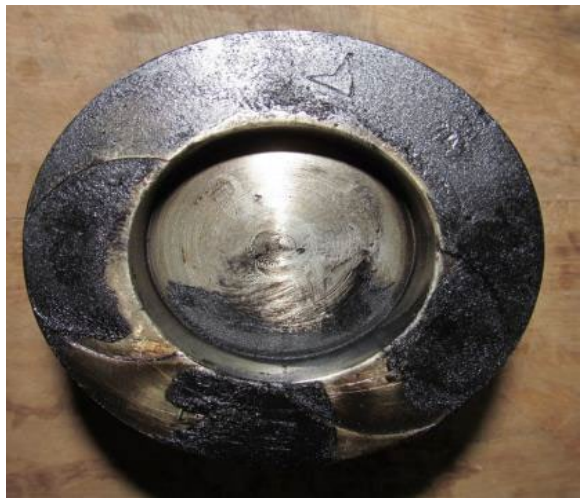

(b) Cylindrical type

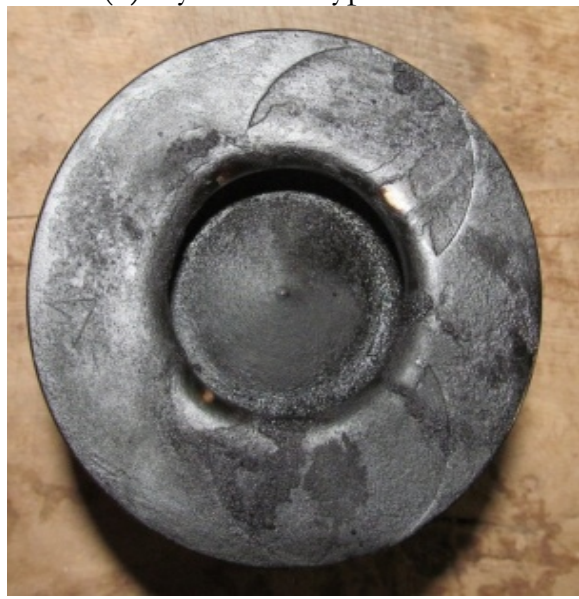

(d) Toroidal Reentrant type

Figure 4. Combustion vestibule shapes

Experimental procedure: The existing direct injection diesel engine with hemispherical bowl piston supplied by manufacturer was having a 3 holes injector with injection pressure set at 205 bar and injection timing at $19^{\circ} \mathrm{bTDC}$ suitable for diesel. For CROME the 3 holes injector was replaced with a 6 holes injector whose injection pressures were varied from 210 bar incrementing by 10 bar for every set up up to 250 bar using a pressure setting gauge. The injection timing was also changed to $23^{\circ} \mathrm{bTDC}$ and $27^{\circ} \mathrm{bTDC}$ in each experiment. The same procedure was carried out for different pistons having cylindrical, Toroidal and Toroidal Re-entrant bowl shapes cut in computerised numerical control machine maintaining same compression ratio of 17.5. Hartridge smoke opacity meter and five gas analyzers were used to measure smoke opacity and HC, CO, and NOx emitted at steady states. When the injection pressure was more than 240 bar and injection timing was $23^{\circ} \mathrm{bTDC}$ the performance was poor may be due to wall wetting and retarded injection timing whose results are not reported here. But the performance was maximised for $240 \mathrm{bar}$ and $27^{\circ} \mathrm{bTDC}$ for all CCS which is reported in this paper. 


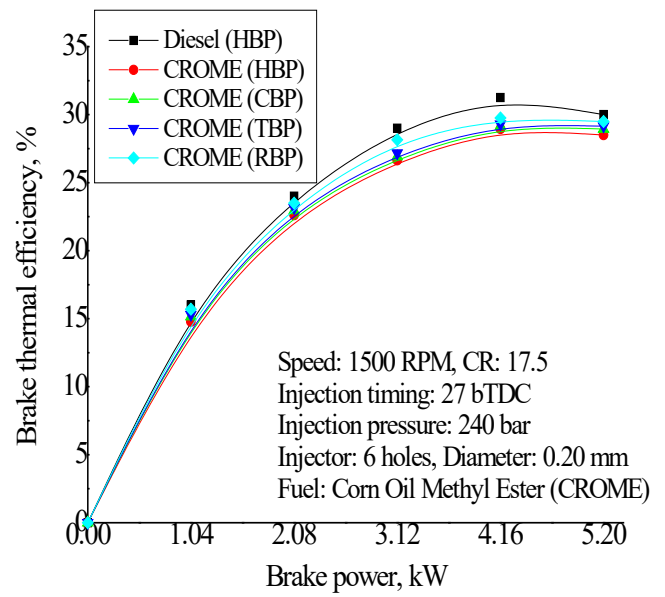

Figure 5. Effect of combustion chamber shapes on brake thermal efficiency

\section{RESULTS AND DISCUSSIONS}

\section{The Effect of Combustion Vestibule Shapes on Competence and Emissions}

The outcome of Hemispherical Bowl Piston (HBP), Cylindrical Bowl Piston (CBP) Toroidal Bowl Piston (TBP) and Re-entrant Bowl Piston (RBP) configurations (cut in a NC machine) on the attributes of the diesel prime mover fuelled with CROME at $80 \%$ load and at IOP of 240 bar and IT of $27^{\circ} \mathrm{bTDC}$ were analysed and presented.

\section{Competence}

Brake thermal efficiency:

Figure 5 presents various combustion chamber shapes (CCS) effect on the brake thermal efficiency. For the use of 6-holes injector and HBP increase in BTE has been observed for diesel operation compared to biodiesel operation. Increase in number of injector holes decreases mass of fuel injected per hole which improves spray formation as reported in literature (Alireza Lotfi and Hassan Ghassemi, 2017, Pyari et al., 2008, Benajes et al., 2004, Hans et al., 2002). Also further it can be stated that increase in BTE decreases mass of fuel injected for a given load and speed which further decreases mass of fuel injected per hole resulting in much more finer spray formation. Variations in fuel properties lead to differences in the thermal efficiency. Experimental study using above mentioned combustion chamber shapes show that re-entrant combustion chamber (RBP) showed enhanced thermal efficiency than the operation with other combustion chambers used. Flame prevention obtained from pervading on the squish-swirl region may result into proper formation of mixture of biodiesel along with air and increased flame propagation is responsible for increased thermal efficiency when RBP was used. The reduced brake thermal efficiency for CROME may be linked to low energy potential of the fuel and hence more fuel being consumed for the similar brake power. Also CROME being more viscous and has high flash point that cause hindrance to form the mix and repercussion is poor combustion than diesel. Biodiesel operation with HBP and CBP lead to increased ignition delay and combustion duration that results in reduced BTE (Gopinath and Suresh, 2015; Nalgundwar et al., 2016; Rajan and senthikumar, 2010; Recai et al., 2011). However, biodiesel operation with TBP resulted in marginally similar thermal efficiency that is obtained with RBP. Use of TBP and RBP witnessed enhanced combustion during the expansion stroke. The brake thermal efficiency for CROME fuel using different combustion vestibule volume shapes of Hemispherical (HBP), Cylindrical (CBP), Toroidal (TBP) and Re-entrant (RBP) were found to be $27.5 \%, 28.1 \%, 28.4 \%$, and $30 \%$ respectively compared to $31.25 \%$ for diesel at 205 bar. For same CROME operation, the BTE with RBP was increased by $2.5 \%$ compared to HBP operation and tends to move closer to diesel performance as can be viewed in Figure 5 which is the main objective of this work as also reported in literature (Channappagoudra et al., 2018). It is proved that the combination of different CCS and 6hole injector at higher IOP of $240 \mathrm{bar}$ and IT of $27^{\circ} \mathrm{bTDC}$ has profound effect on performance. Also compared to 3 holes injector with HBP, increase in BTE for 6 holes injector with RBP is by $5 \%$ according to our previous work. At very high IOP of 250 bar and more, fuel spray may be superfine but has low momentum and relative velocity with respect to swirling air. Hence spray penetration in compressed air is not sufficient and less amount of air takes part in combustion which may be poor as reported in literature by Channappagoudra et al. 2018. In their research they found that for B20 (20\% biodiesel) above 230 bar BTE reduced and it increased by $4 \%$ at IOP of 230 bar. 


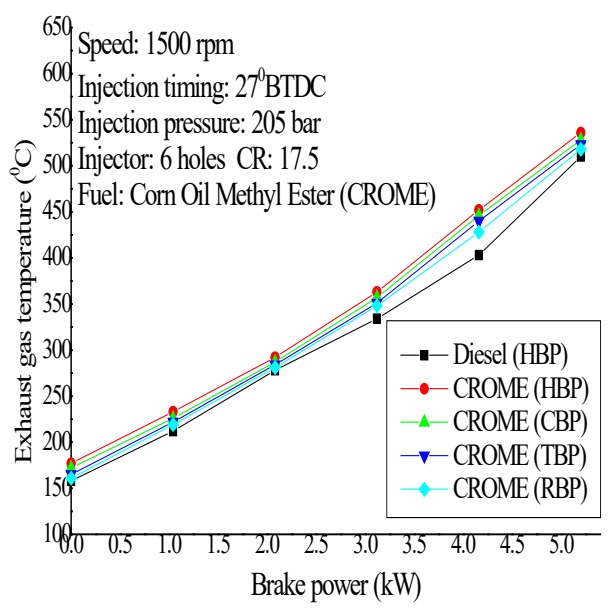

Figure 6. Effect of combustion chamber shapes on exhaust gas temperature

Ravichandran et al. (2016) studied the effect of HBP and TBP in a CI engine fuelled with 100\% corn oil methyl ester (COME) using 3 holes injector available in existing kirloskar engine and got BTE of 24\% and 26\% obtained from their graph. But in our work the corresponding values are BTE of $27.5 \%$ and $30 \%$ which may be due to use of 6 holes injector.

\section{Exhaust Gas Temperature:}

Figure 6 presents exhaust gas temperature variation with different CCS and diesel combustion with same HBP resulted in lower values in comparison to CROME operation. For biodiesel more exhaust gas temperature may be caused by improper air-fuel mixing leading to reduced oxidation rate resulting in more afterburning. But for the similar operating conditions, biodiesel combustion using RBP comparatively resulted in lower temperature of exhaust gases than other CCS. Running the engine with RBP resulted in improvised air-fuel mixing due to better turbulence taking place in the combustion chamber that leads to enhanced soot particles oxidation as reported in literature (Bharathi and Prasanthi, 2011; McCracken and Abraham, 2001). It is observed that TBP also resulted in similar results as that of RBP. Enhanced turbulent kinetic energy with RBP compared to HBP and CBP is also accountable for this trend of result. exhaust gas temperature for CROME fuel using various CCS of Hemispherical (HBP), Cylindrical (CBP), Toroidal (TBP) and Re-entrant (RBP) were found to be $450,440,430,425^{\circ} \mathrm{C}$ respectively compared to $380^{\circ} \mathrm{C}$ for diesel at 205 bar. Hence when CCS was changed from HBP to RBP, exhaust gas temperature for CROME fuel decreased by $25^{\circ} \mathrm{C}$ i e by $5.55 \%$ and tends towards that of diesel. It may be due to strong squish and re-entry swirl developed in toroids leading to improved combustion. Higher exhaust gas temperature indicates that there is more afterburning or late burning which may be due to poor mixture formation with HBP CC. But for TBP and RPB due to strong squish, air and fuel mix up and burn at faster rate reducing afterburning resulting in lower exhaust gas temperature. It indicates that due to enhanced turbulent kinetic energy most of the combustion has taken place in premixed or uncontrolled combustion and in diffusion or controlled combustion stages reducing the quantity of fuel that burns in afterburning as also reported by Alireza Lotfi and Hassan Ghassemi (2017) that the rotation in the compaction stage and the quality of air movement in the combustion chamber were improved from HBP to RBP. This results in higher values of peak pressure and temperature thus increasing mean effective pressure resulting in increased work done and brake or overall thermal efficiency.

Also Ravichandran et al. (2016) reported that the gas temperature in the exhaust for COME with HBP and TBP are 507 and $489^{\circ} \mathrm{C}$ respectively at full load which shows that there is more afterburning. In our work the corresponding values are 450 and $425^{\circ} \mathrm{C}$ which shows that there is less afterburning which may be due to use of 6 holes injector.

\section{Emissions}

Smoke Emissions:

Figure 7 presents smoke intensity or opacity variation due to different CCS. Diesel combustion with same combustion chambers resulted in lower levels of smoke in comparison to CROME operation. It may be result of improper air-fuel mixture leading to reduced oxidation rates of biodiesel burning. For the similar operating conditions, biodiesel combustion using RBP concluded smoke being less opaque contrasted with other CCS. Running engine with RBP concluded in meliorated air-fuel mixing due to improvised turbulence taking place in the combustion vestibule volume that leads to correct combustion and sooty carbon particles oxidation. In 


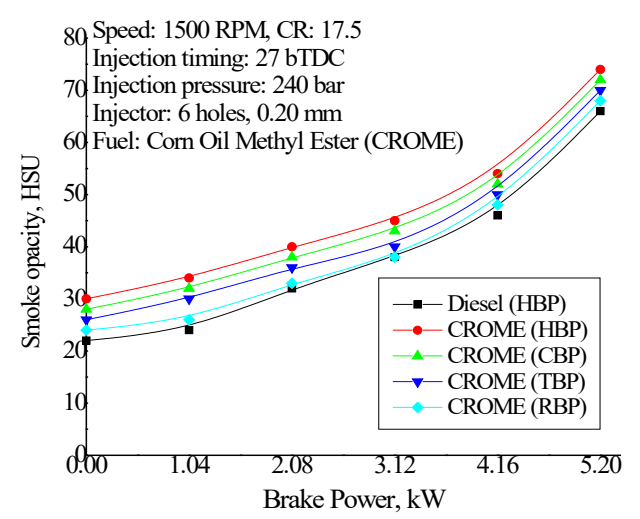

Figure 7. Effect of combustion chamber shapes on smoke opacity

addition, it may lower the smoke levels. It is observed that TBP also resulted in similar results as that of RBP. Enhanced turbulent kinetic energy with RBP compared to HBP and CBP is also accountable for this trend of result as also reported by Alireza Lotfi and Hassan Ghassemi (2017). In their two piece piston design with squish area of $30 \%$ piston bowl, combustion improved and reduced emissions. Also they reported that factors such as turbulence, kinetic energy and rotation in the compaction stage and the quality of air movement in the combustion chamber were improved from HBP to RBP. Smoke opacity for CROME and CROME fuel using various CCS of Hemispherical (HBP), Cylindrical (CBP), Toroidal (TBP) and Re-entrant (RBP) were found to be respectively 54, 52, 50, 46 HSU contrasted to 44 HSU for diesel at 205 bar. Hence when CCS was changed from HBP to RBP, smoke levels for CROME fuel decreased by $8 \mathrm{HSU}$ i e by $14.8 \%$ and tends towards that of diesel. It may be due to strong squish and re-entry swirl developed in toroids and use of 6-hole injector leading to improved combustion.

\section{$\mathrm{HC}$ and $\mathrm{CO}$ emissions:}

Figures 8 and 9 present the outcome of different combustion chambers on the HC-CO emission levels for diesel and CROME operation. Decreased lesser average effective pressure is accountable for larger HC-CO emissions in case of CROME operation. From the Figures 4 and 5 it is viewed that RBP concluded in lower HCCO levels contrasted to other CCS as also reported in literature by Channappagoudra et al., 2018 i.e. HC, and CO emissions were decreased by 15\%, and 14.47\%, respectively for B20 (diary scum oil biodiesel) but not for complete replacement. RBP ensures improvised combustion of BDF due to proper squishing (radial inward motion of gases during compression stroke into toroids causing induced swirl) and tumbling motion resulting in enhanced BTE. Hence biodiesel operation with RBP has better performance compared to other combustion chambers. TBP also recorded similar trends, but slightly lagging behind RBP for BDF operation. But comparatively biodiesel operation in HBP and CBP may have resulted in lower swirl rate and improper mixing of gases leading to partial burning. The same result is reported by Channappagoudra et al., 2018, Jaichander and Annamalai, 2012, Matsumoto et al., 1977. Channappagoudra et al., 2018, modified existing hemispherical piston bowl geometry (HPBG) into toroids piston bowl (TPB) to measure the performance of scum oil of dairy and its B20 biodiesel and using 5 holes injector. In their experiments $\mathrm{HC}$ and $\mathrm{CO}$ emissions were decreased as given above in this section. Such improvements using the TPB may be due to improved fuel atomization thus reducing fuel droplet size, higher cylinder temperature, enhanced swirl-squish and kinetic turbulent energy during burning process. Jaichandar and Annamalai, 2012, experimentally studied the B20 (20\% POME) in Toroidal combustion vestibule with deep toroids and a shallow re-entrance and found that RBP decreased the NOx emissions to the maximum when contrasted with baseline HBP. They analyzed that the RBP tends to improvise the mixture formation by squishing and reentry resulting in decreased HC-CO emissions. Diesel fuel combustion with HBP resulted in decreased HCCO emissions compared to CROME due to disparity in properties of biodiesel and petro diesel. For CROME fuel operation, at 80\% load, HC emissions using Hemispherical (HBP), Cylindrical (CBP), Toroidal (TBP) and Reentrant (RBP) were found to be respectively $43 \mathrm{ppm}, 42 \mathrm{ppm}, 40 \mathrm{ppm}$ and $38 \mathrm{ppm}$ for CROME compared to 36 ppm for Diesel fuel. Hence when CCS was changed from HBP to RBP, HC emissions for CROME fuel decreased by $5 \mathrm{ppm}$ i e by $11.6 \%$ and tends towards that of diesel. It may be due to strong squish and re-entry swirl developed in deep toroids leading to improved combustion. 


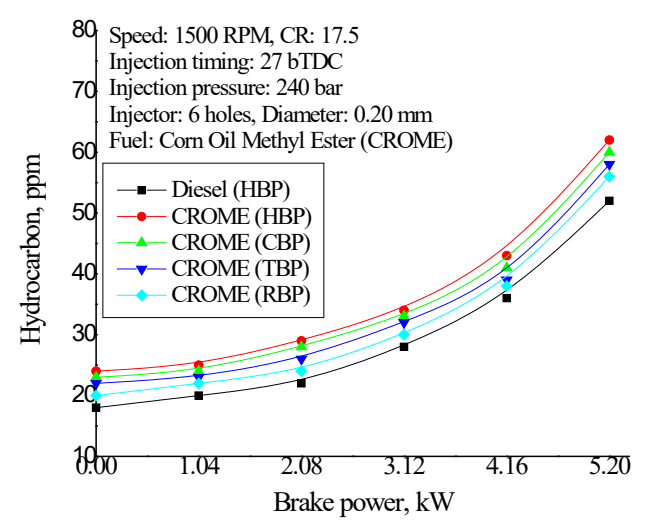

Figure 8. Effect of combustion chamber shapes on HC emissions

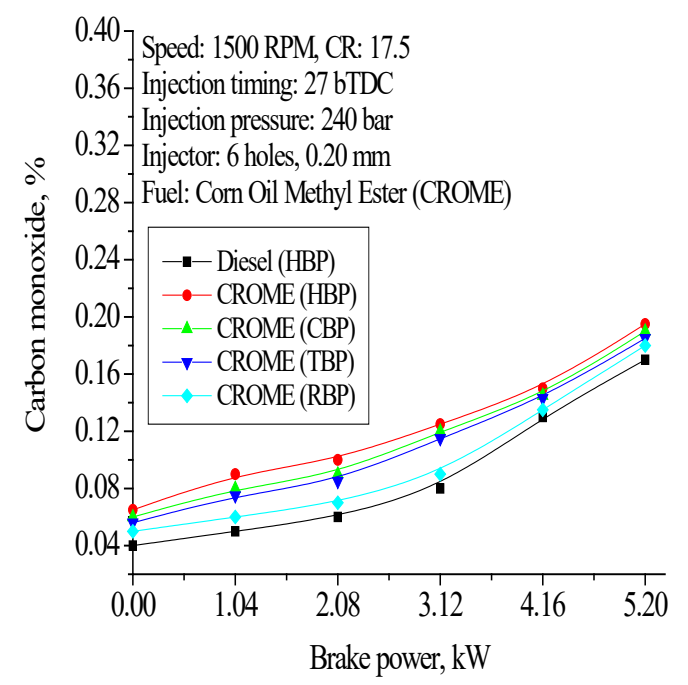

Figure 9. Effect of combustion chamber shapes on CO Emanations

\section{$\mathrm{NO}_{\mathrm{x}}$ emissions:}

Biodiesels of different origin when used with same combustion chambers, have lower NOx emissions contrasted to Diesel operation as presented in Figure 10. It may be caused by the enhanced combustion of Diesel during uncontrolled combustion stage. Biodiesel combustion with RBP concluded in better oxygen utilization during combustion facilitated by meliorated swirl and turbulence compared to other CCS. However for the same combustion chamber, CROME fuel operation lead to marginally lesser NOx contrasted to working with diesel as also reported by Praveena et al. (2017), Hountalas et al. (2001), there was appreciable reduction in biodiesel NOx in their work due to reduction in peak temperature. This could be accounted to retarded burning of CROME fuel during initial stages of combustion caused by the lagging air-fuel mixing rates resulting in lower peak temperature. As shown in Figure 9 CO emissions using Hemispherical (HBP), Cylindrical (CBP), Toroidal (TBP) and Reentrant (RBP) were found to be $0.15 \%, 0.14 \%, 0.14 \%, 0.12 \%$ for CROME contrasted to $0.11 \%$ at $80 \%$ of full load for Diesel. Hence when CCS was changed from HBP to RBP, CO emissions for CROME fuel decreased by $0.03 \%$ and tends towards that of diesel. 


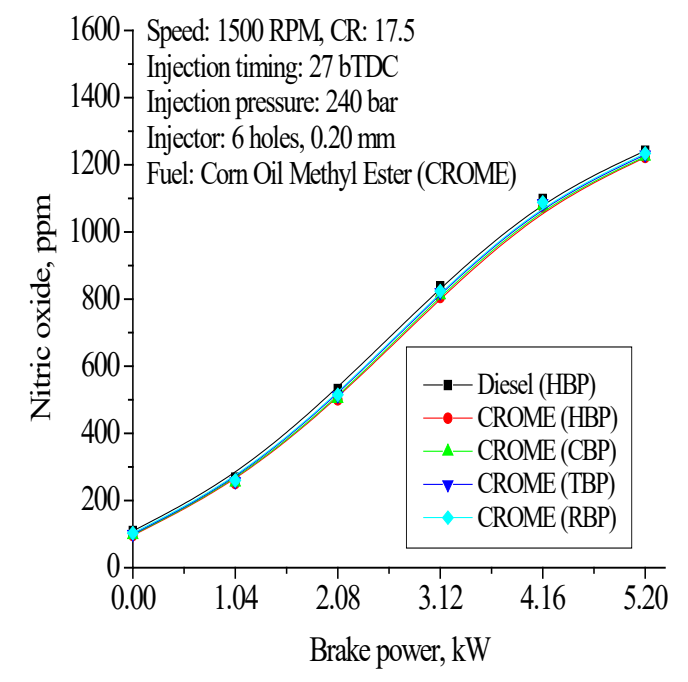

Figure 10. Effect of combustion chamber shapes on NOx emissions

Also Ravichandran et al. (2016) reported that the NOx emissions in the exhaust for COME with HBP and TBP are $812 \mathrm{ppm}$ and $843 \mathrm{ppm}$ respectively which shows that there was slow rate of combustion with increased CD resulting in more BTL. In our work the corresponding values are $1100 \mathrm{ppm}$ which shows that there is higher peak temperature attained due to improved combustion may be due to use of 6 holes injector which augments NOx formation.

\section{The Effect of Combustion Chamber Shapes (CCS) on Parameters of Combustion}

This section explains the outcome of CCS on the combustion attributes of the diesel prime mover run with CROME at $80 \%$ load and at IOP of 240 bar and IT of $27^{\circ} \mathrm{bTDC}$, were analysed and presented. Combustion parameters namely peak pressure, delay period, combustion duration, variation of pressures and rates of heat releases have been presented in the succeeding analysis.

\section{Combustion attributes}

Peak Pressure:

Figure 11 shows how the peak pressure varies with brake power running with CROME and Petroil for CCS selected. Maximum pressure and of maximum pressure rise rate were larger with diesel operation contrasted to CROME usage and it may be caused by proper combustion of base (diesel) fuel. However, lower calorific value and incomplete burning because of heavier molecular weight fatty acids of biodiesel may be amenable for these trends of the outcomes. RBP results into higher PP as it provides swirl associated with turbulence in the toroids and the concluding meliorated air-fuel mixture combustion could be amenable for these trends as also reported in literature by Changchun Xu et al. (2018). However, TBP performs close to that of RBP followed by CBP and HBP. Combustion chamber being same, the CROME operation concluded in slightly lower maximum pressure than diesel fuel use. Properties of the injected liquid fuels are amenable for the observed trends. The peak pressure with diesel (HBP) and CROME (RBP) fuel operation are found to be 76 bar at about $10^{\circ} \mathrm{CA}$ aTDC and 73 bar at $8^{\circ} \mathrm{CA}$ aTDC respectively. Also for CROME maximum pressure increased from 70 bar at $4^{\circ} \mathrm{CA}$ aTDC to 73 bar at $8^{\circ} \mathrm{CA}$ aTDC when CCS changed from HBP to RBP. Thus it can be concluded that piston bowl shapes have profound outcome on competence of diesel prime mover (Gajendra Babu, 2007; Godiganur et al., 2009; Muralidharan and Vasudevan, 2011; Nwafor, 2003; Sakthisaravanasenthil et al., 2017). 


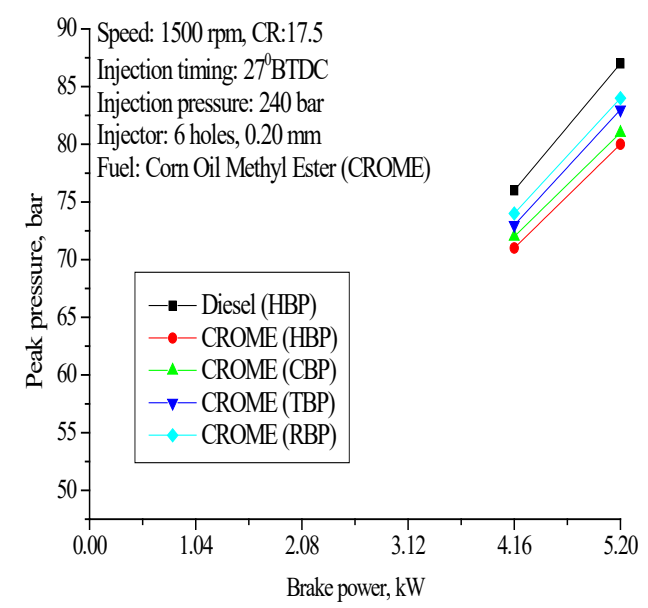

Figure 11. Effect of combustion chamber shapes on peak pressure

The above results match with that in literature as Ramesh Bapu et al. (2015), i.e they reported that due to higher specific heats the exhaust gases were absorbing more heat thereby reducing peak pressure and high temperature attained. Their conclusion was that at CR18 for B20 blend, the PP values were 54.04 bar at $6^{\circ} \mathrm{CA}$ aTDC for HCC, 57.28 bar at $5^{\circ} \mathrm{CA}$ aTDC for MHCC but for diesel values are 54.66 bar at $6^{\circ} \mathrm{CA}$ aTDC for HCC. So, the peak pressure increase by $4.8 \%$ for MHCC than in HCC for diesel due to more amount of fuel burning in the premixed combustion stage due to change in ID duration.

The deep toroids of RBP act as adiabatic swirl chambers reducing heat loss to cylinder walls thus resulting in maximum PP and peak temperature. This effect is same as research work of Nagarsheth and Gossay, 2016, who fabricated two different types of TBC (thermal barrier coating) combustion chambers coated with $\mathrm{MgZrO} 3(\mathrm{MgZrO} 3$ magnesium zirconium oxides) and YSZ (Yttria stabilize Zirconia). Out of two TBC materials $\mathrm{MgZrO} 3$ was better which gave complete combustion with higher HRR. Due to coating compression pressure was increased by 10.50 percent with more work output and increased thermal efficiency.

Ignition Delay:

Figure 12 presents the outcome of CCS on ignition delay (ID). With increase in engine power output the amount of fuel consumed also increased. This also leads to higher in-cylinder gases temperature. Viscosity and volatility differentials of biodiesel may be amenable for increased ID as contrasted to diesel fuel operation as also reported in literature (Onga et al., 2011). BDF needs more time to burn due to higher viscosity at no load and part loads as well. But as load increases the ID of BDF decreased due to increased combustion temperatures. It may be due to the improvised air-fuel mixing at higher combustion temperatures. RBP shows lower ID as its geometry meliorates rate of mixture formation due to swirling gas motion in deep Toroids which allows for re-entry of burning gases resulting in better combustion and hence enhanced combustion temperature as also reported by Jaichander and Annamalai (2012), Matsumoto et al. (1977). CC being common, properties of injected fuel results in the ID variations and accordingly for CROME operation the ID was found to be slightly more contrasted to Diesel. Late burning of CROME fuel may be amenable for this feature when contrasted to Diesel. At $80 \%$ load with RBP, the ID for CROME and Diesel is found as 10.5 degree CA (Crank Angle) and 10 degree CA respectively. Also for CROME the ID decreased from 11 degree CA to 10.5 degree CA (same as that of diesel) when CCS changed from HBP to RBP as reported by Praveena et al. (2018) and Ramesh Bapu et al. (2015). Even though ID decrease marginally it results in peak pressure nearer to TDC position, which acts through larger stroke length leading to more work done and higher thermal efficiency. 


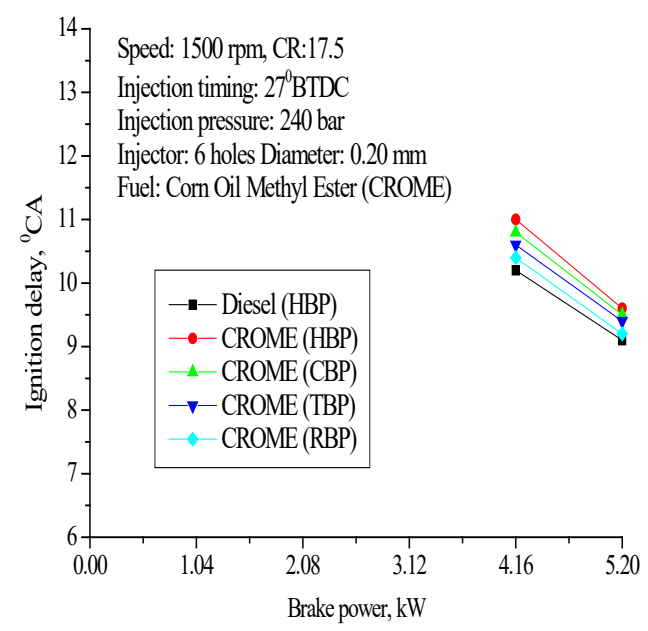

Figure 12. Effect of combustion chamber shapes on ignition delay

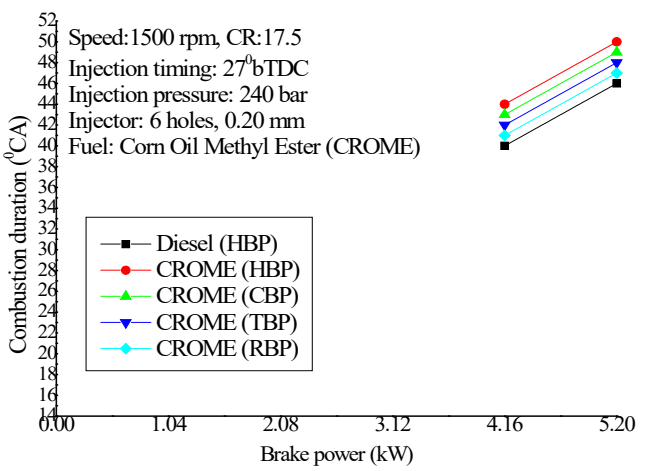

Figure 13. Effect of combustion chamber shapes on combustion duration

The above results match with that in literature as Ramesh Bapu et al. (2015) reported that the ID range for Calophyllum Inophyllum Methyl Ester (CIME) in HCC was $16^{\circ}$ to $10^{\circ} \mathrm{CA}$ and for Modified HCC (MHCC) was $16^{\circ}$ to $8^{\circ} \mathrm{CA}$ while for diesel in $\mathrm{HCC}$ was $8^{\circ} \mathrm{CA}$ to $12^{\circ} \mathrm{CA}$. Thus ID of biodiesel blend $\mathrm{B} 20$ is almost same as that of diesel and it reduces with the increase in load and higher cylinder temperatures.

\section{Combustion Duration:}

Figure 13 shows how the combustion duration (CD) varies with brake power running with CROME and Petroil for CCS selected. CD was higher for CROME when compared to diesel fuel use. This fact may be caused by disparities in fuel properties. However, the CD for biodiesel was found to be lesser for the engine with RBP and TBP. Due to higher IOP of 240 bar Biodiesel concluded in higher uncontrolled premix explosion stage associated with higher BTE as studied by Kruczynski et al. (2013), who reported that variations in operating conditions play paramount role to improve performance. RBP and TBP provide improvised mixing of fuel with air due to increased squishing-swirling, ensuring lesser CD as also reported by Jaichander and Annamalai (2012), Matsumoto et al. (1977). However, results showed that the combustion of biodiesel with CBP and HBP was not favoured positively. In addition, for the same combustion chamber CROME operation showed slightly more CD in comparison to Diesel operation. This could be due to differences in their fuel properties. At $80 \%$ load the CD is 42 degree CA and 39 degree CA for CROME and Diesel respectively. Also CROME the ignition delay decreased from 44 to 42 degree CA when CCS changed from HBP to RBP which decreases BTL and improves efficiency. Even though CD decrease marginally it results in shifting of peak pressure towards TDC position, which acts through larger stroke length leading to more work done and higher thermal efficiency.

\section{Cylinder pressure and heat release rates}

The history of cylinder pressure-crank angle data was acquired for 100 cycles and the ensembled average pressure differential with crank angle at $80 \%$ load is shown in Figure 14 for different combustion chamber shapes. The cylinder pressure relies on the rate at which combustion progress and portion of fuel that take part in rapid combustion period. How the mixture forms during ID and its quality regulates premixed-rapid combustion stage 


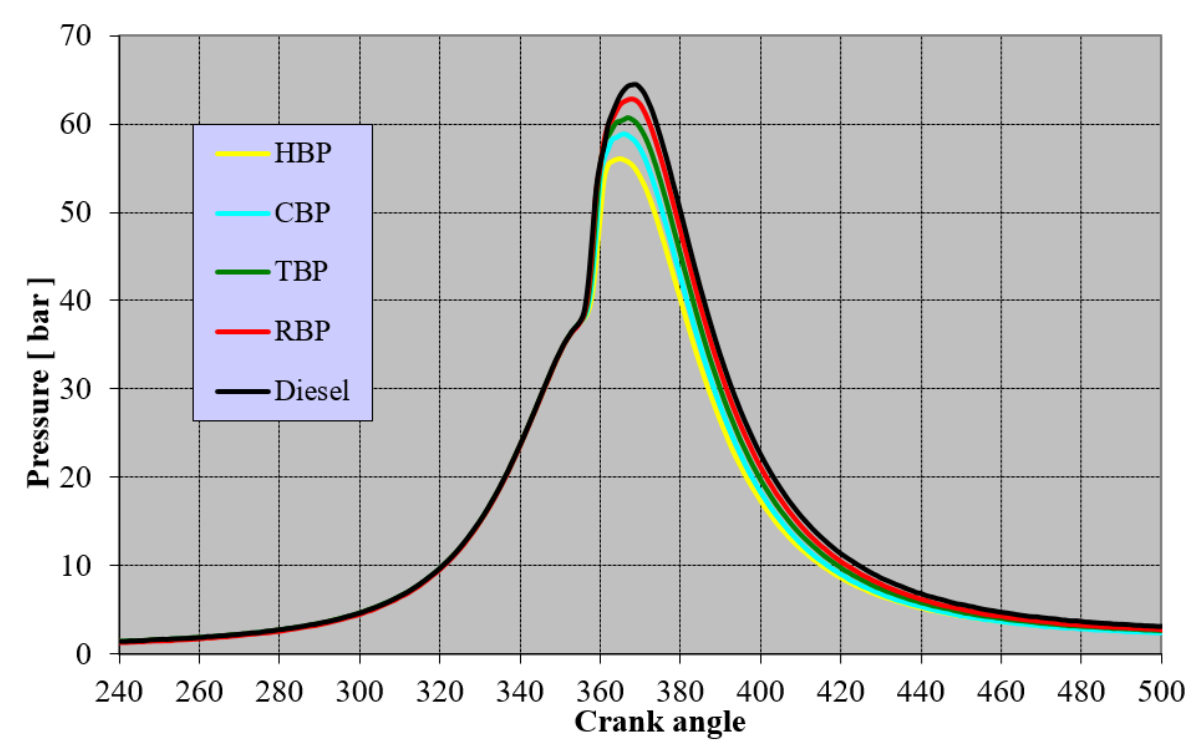

Figure 14. Effect of combustion chamber shapes on cylinder pressure

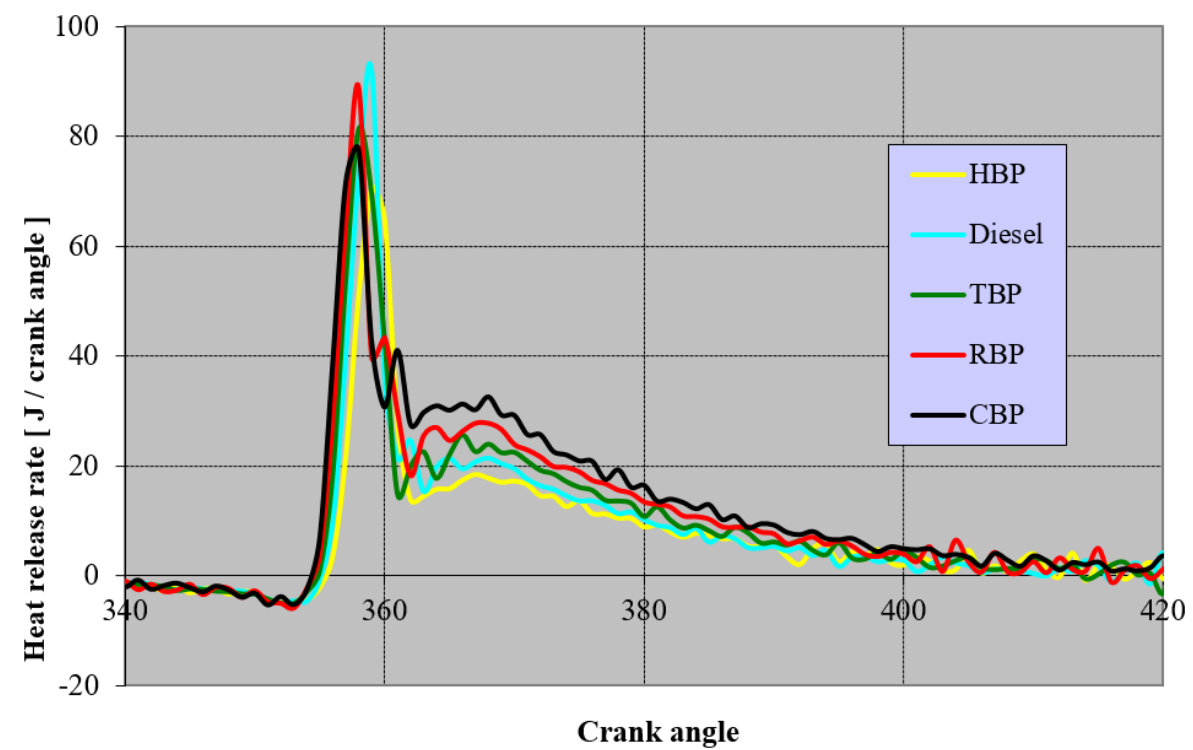

Figure 15. Effect of combustion chamber shapes on HRR

which is also amenable for the PP and maximum rate of pressure rise as reported by Praveena, et al., 2018. Slightly lower peak pressure was noticed when engine was running on CROME fuel with different combustion chamber shapes as compared to diesel. The reason could be higher viscosity and slower heat release of CROME. Similarly, how HRR varies with crank angle is seen in Figure 15. CROME showed slightly lower HRR as compared to diesel with all combustion chambers used, could be due to slower burning rate of CROME as it is more viscous and has lower cetane number. But again RBP performed well with high PP and HRR very close to that of diesel as also reported in literature by Changchun Xu et al. (2018) who found that the double round bottom shape in piston surface similar to RBP has more influence than the other shapes in compacting and promoting the mixture formation which resulted in higher PP and HRR. They also concluded that changes in piston crown shapes produce differing TSM (tumbling-swirling motion) and KTE (kinetic turbulent energy) levels. Hence for CROME PP increased by 8 bar and by $14.54 \%$, HRR increased by $20 \mathrm{~J} / \mathrm{CA}$ and by $28.57 \%$, when CCS changed from HBP to RBP.

\section{CONCLUSIONS}

The stochastic inquest on the viability of CROME in diesel prime mover at $80 \%$ load and at IOP of $240 \mathrm{bar}$ and IT of $27^{\circ} \mathrm{bTDC}$ shows that the competence was slightly inferior contrasted to diesel. It is because CROME is more viscous and has high flash point hence rate of evaporation and mixing with air is slow. BTE of CROME was $26.5 \%$ which is close to $31.5 \%$ for diesel both with HBP. But by RBP the efficiency of biodiesel increased to $30 \%$. 
The geometry of RBP ameliorates rate of mixture formation due to squishing-swirling gas motion in deep Toroids which allows for faster and faster re-entry of burning gases into swirl again and again resulting in better combustion.

The exhaust smoke temperature, CO, HC and smoke emissions were lesser for RBP due to fastened air-fuel mixing and substantial oxygen present in CROME and better burn rate contrasted to HBP, CBP and TBP type CCS. But NOx was almost same as that of diesel for all types which was $1100 \mathrm{ppm}$. Also reduced ID (by $1^{\circ} \mathrm{CA}$ ) and $\mathrm{CD}$ (by $3^{\circ} \mathrm{CA}$ ) resulted in decreased BTL increasing performance for RBP type combustion vestibule.

Higher peak pressures were obtained with diesel (HBP) followed by CROME (RBP) fuel operation due to higher pre-mixed combustion and lowered diffusion combustion phase at $80 \%$ load. The performance of CROME fuelled engine approached that of diesel when provided with increased 6 holes injector which sprays fuel into the engine cylinder as micro fine droplets at higher IOP of $240 \mathrm{bar}$ and advanced IT of $27^{\circ} \mathrm{bTDC}$ effecting improved air-fuel distribution. Therefore, CROME is better alternative fuel source for conventional diesel prime mover. From combustion graphs it is to be noted that for CROME, RBP has higher competence than other combustion chamber shapes (CCS) and has HRR and PP of $90 \mathrm{~J} /$ crank angle and 63 bar respectively very close to that of diesel i.e. $98 \mathrm{~J} /$ crank angle and 65 bar respectively satisfying our main objective of this work. Therefore this research work shows that the CROME is capable of replacing diesel by $100 \%$ in a conventional diesel engine.

Generalisation of result of this research: The geometry of RBP improves rate of mixture formation due to swirling gas motion in deep Toroids which allows for faster rates of combustion and higher performance for CROME. As most of the biodiesels have similar thermal properties it can be generalised that similar performances can be anticipated for other CCS and biodiesels also.

Weaknesses/Limitations and Future work recommendations: The research on CROME and other biodiesels can be further carried out by using 7 holes injector, inventing different CCS and by varying operating conditions. The analysis can be done by CFD, simulation and modelling to get more details of movement of combustion gases inside cylinder which can be considered for design of engine hardware. All experiments can be conducted in variable compression ratio diesel engines for conventional and common rail direct injection (CRDI) engine systems. These variations are not done in these works which are the weaknesses/limitations. The literature survey shows that $100 \%$ biodiesel use lead to deposits on various components of engine, creating problems and decreasing performance. Hence in our works same can be carried out.

\section{REFERENCES}

Arifin, Y. M. and Arai, M. (2009). Deposition characteristics of diesel and bio-diesel fuels. Fuel, 88(11), 2163-2170. https://doi.org/10.1016/j.fuel.2009.01.021

Banapurmath, N. R. and Tewari, P. G. (2009). Effect of biodiesel derived from Honge oil and its blends with diesel when directly injected at different injection pressures and injection timings in single cylinder water cooled compression ignition engine. Proceedings of Institute of Mechanical Engineers, Part A: Journal of Power and Energy, Professional Engineering Publications, 223(1), 31-40. https:/ / doi.org/10.1243/09576509JPE673

Bari, S., Lim, T. H. and Yu, C. W. (2002). Effect of Preheating of Crude Palm Oil (CPO) on Injection System, Performance and Emission of a Diesel Engine. Renewable Energy, 27, 339-351. https://doi.org/10.1016/S09601481(02)00010-1

Bari, S., Yu, C. W. and Lim, T. H. (2004). Effect of fuel injection timing with waste cooking oil as a fuel in direct injection diesel engine. Proceedings of the Institution of Mechanical Engineers, Part D: Journal of Automobile Engineering, 218, 93-104. https://doi.org/10.1243/095440704322829209

Bawankar, C. S. and Gupta, R. (2016). Effects of piston bowl geometry on combustion and emission characteristics on diesel engine: ACFD case study. International Journal of Research in Engineering and Technology, 05, 81-93. https:// doi.org/10.15623/ijret.2016.0507015

Benajes, J., Pastor, J. V., Pyari, R. and Plazas, A. H. (2004). Analysis of the influence of diesel nozzle geometry in the injection rate characteristics. Journal of Fluids Engineering, 126, 63-71. https:// doi.org/10.1115/1.1637636

Bharathi Pratiba, V. V. and Prasanthi, G. (2011). Influence of in cylinder air swirl on diesel engine performance and emission. International Journal of Applied Engineering and Technology, 1, 113-118.

Caceres, D., Reisel, J. R., Sklyarov, A. and Poehlman, A. (2003). Exhaust emission deterioration and combustion chamber deposits composition over the life cycle of small utility engine. J. Eng. Gas Turbines Power, 125(1), 358364. https://doi.org/10.1115/1.1496773

Chaichan, M. T. (2015). Performance and emission study of diesel engine using sunflowers oil-based biodiesel fuels. International Journal of Scientific and Engineering Research, 6(4), 260-269.

Channappagoudra, M., Ramesh, K. and Manavendra, G. (2018). Comparative investigation of the effect of hemispherical and toroidal piston bowl geometries on diesel engine combustion characteristics. Biofuel Research Journal, 19, 854-862. https://doi.org/10.18331/BRJ2018.5.3.5 
Fangsuwannarak, K., Wanriko, P. and Fangsuwannarak, T. (2016). Effect of Bio-polymer Additive on the Fuel Properties of Palm Biodiesel and on Engine Performance Analysis and Exhaust Emission. Energy Procedia, 100, 227-36. https://doi.org/10.1016/j.egypro.2016.10.170

Forson, F. K., Oduro, E. K. and Hammond-Donkoh, E. (2004). Performance of Jatropha oil blends in a diesel engine. Renew Energy, 29, 1135-45. https://doi.org/10.1016/j.renene.2003.11.002

Gajendra Babu, M. K. (2007). Studies on performance and exhaust emissions of a CI engine operating on diesel and diesel biodiesel blends at different injection pressures and injection timings. Society of Automotive Engineers, Paper No.: 2007-01-0613, USA.

Gajendra Babu, M. K., Kumar, C. and Das, L. M. (2006). Experimental Investigations on a Karanja Oil Methyl Ester Fuelled DI Diesel Engine. Society of Automotive Engineers, Paper No.: 2006-01-0238, USA.

Godiganur, S., Murthy, C. and Reddy, R. P. (2009). 6BTA 5.9 G2-1 Cummins engine performance and emission tests using methyl ester mahua (Madhuca indica) oil/diesel blends. Renewable Energy, 34, 2172-2177. https://doi.org/10.1016/j.renene.2008.12.035

Goldemberg, J. and Coelhobn, S. T. (2004). Renewable energy- traditional biomass vs. modern biomass. Energy Policy, 32, 711-714. https://doi.org/10.1016/S0301-4215(02)00340-3

Gopinath, V. and Suresh, P. (2015). Experimental Study on the Emission Characteristics of a Diesel Engine Using Corn Oil as Fuel. International Journal of Renewable Energy research, 15(1), 99-110.

Gosai, D. C. and Nagarsheth, H. J. (2016). Diesel engine cycle analysis of two different tbc combustion chamber. Procedia Technology, Elsevier, Science Direct, 23, 504-512. https://doi.org/10.1016/j.protcy.2016.03.056

Hans, J. S., Lu, P. H., Xie, X. B., Lai, M. C. and Henein, N. A. (2002). Investigation of diesel spray primary breakup and development for different nozzle geometries. Society of Automotive Engineers, Paper No: 2002-01-2775, USA. https:// doi.org/10.4271/2002-01-2775

Hountalas, D. T., Kouremenos, D. A., Binder, K. B., Raab, A. and Schnabel, M. H. (2001). Using advanced Injection timing and EGR to Improve DI engine efficiency at Acceptable NO and Soot levels' Society of Automotive Engineers, Paper No.: 2001-01-0199, USA. https:// doi.org/10.4271/2001-01-0199

Jaichander, S. and Annamalai, K. (2012). Effects of open combustion chamber geometries on the performance of pongamia bodiesel in a DI diesel engine. Fuel, 98, 272-279. https://doi.org/10.1016/j.fuel.2012.04.004

Jaichander, S. and Annamalai, K. (2013). Combined impact of injection pressure and combustion chamber geometry on the performance of a biodiesel fueled diesel engine. Energy, 47, 388-394. https://doi.org/10.1016/j.energy.2012.09.059

Jatadhara, G. S. and. Chandrashekar, T. K. (June, 2018). Assessment on performance and emission parameter of diesel engine using waste plastic oil used as a fuel. IOP Conf. Ser.: Mater. Sci. Eng, 376, 012020. https://doi.org/10.1088/1757-899X/376/1/012020

Jegan, P. S., R, Balasubbramanian, K. and Nagarajan, G. (2009). Effect of injection pressure on performance, emission and combustion characteristics of high linolenic linseed oil methyl ester in a DI Diesel engine. Renewable Energy, 34, 1227-1233. https:// doi.org/10.1016/j.renene.2008.10.001

Karnwal, A., Kumar, N., Hasan, M. M., Chaudhary, R., Siddiquee, A. N. and Khan, Z. A. (2010). Production of Biodiesel from Thumba Oil: Optimization of Process Parameters. Iranica', Joumal of Energy \& Environment, 1, 352-358. https://doi.org/10.5958/j.0976-3015.1.2.023

Kruczynski Stanislaw, W. (2013). Performance and emission of CI engine fuelled with camelina sativa oil. Energy Conversion and Management, 65, 1-6. https://doi.org/10.1016/j.enconman.2012.06.022

Kus, R. (2011). The effect of raw corn oil and diesel fuel mixture on engine performances and emissions. Energy Education Science and Technology Part A: Energy Science and Research, 28(1), 469-474.

Li, X, Qiao, Z., Su, L., Li, X. and Liu, F. (2016). The combustion and emission characteristics of a multi-swirl combustion system in a DI diesel engine. Applied Thermal Engineering, 15, 1203-1212. https://doi.org/10.1016/j.applthermaleng.2016.10.028

Lotfi, A. and Ghassemi, H. (2017). A Review on the Different Geometries of Combustion Chamber in CI Engines on Performance. Ignition and Emission Journal of Atmospheric Pollution, 5(2), 40-46. https://doi.org/10.12691/jap$5-2-1$

Matsumoto, K., Inoue, T., Nakanishi, K. and Okumura, T. (1977). The effects of combustion chamber design and compression ratio on emissions, fuel economy and octane number requirement. Society of Automotive Engineers, Paper No.: 770193. https:// doi.org/10.4271/770193

McCracken, M. E. and Abraham, J. (2001). Swirl-Spray Interactions in a Diesel Engine'. Society of Automotive Engineers, Paper No.: 2001-01-0996, USA. https://doi.org/10.4271/2001-01-0996

Montajir, R., Tsunemoto, H. and Minami, T. (2000). Fuel spray behaviour in a small DI diesel engine: effect of combustion chamber geometry. Society of Automotive Engineers, Paper No.: 2000-01-0946, USA. https://doi.org/10.4271/2000-01-0946 
Mulemane, A., Hans, J. S., Lu, P. H., Yoon, S. J. and Lai, M. C. (2004). Modelling dynamic behavior of diesel fuel injection systems. Society of Automotive Engineers, Paper No.: 2004-01-0536, USA. https:/ / doi.org/10.4271/200401-0536

Muralidharan, K. and Vasudevan, D. (2011). Performance, emission and combustion characteristics of a variable compression ratio engine using methyl esters of waste cooking oil and diesel blends. Applied Energy, 88, 39593968. https:// doi.org/10.1016/j.apenergy.2011.04.014

Nalgundwar, A., Paul, B. and Sharma, S. K. (2016). Comparison of performance and emissions characteristics of DI CI engine fuelled with dual biodiesel blends of palm and jatropha. Fuel, 173, 172-9. https://doi.org/10.1016/j.fuel.2016.01.022

Nwafor, O. M. I. (2000). Effect of advanced injection timing on the performance of rapeseed oil in diesel engines. Renewable Energy, 21, 433-44. https:/ / doi.org/10.1016/S0960-1481(00)00037-9

Nwafor, O. M. I. (2003). The effect of elevated fuel inlet temperature on performance of diesel engine running on neat vegetable oil at constant speed conditions. Renewable Energy, 28, 171-81. https://doi.org/10.1016/S09601481(02)00032-0

Onga, H. C., Mahlia, T. M. I., Masjukia, H. H. and Norhasyimab, R. S. (2011). Comparison of palm oil, Jatropha curcas and Calophyllum inophyllum for Biodiesel. Renewable and Sustainable Energy Reviews, 15, 3501-3515. https://doi.org/10.1016/j.rser.2011.05.005

Prasad, B. V. V. S. U., Sharma, C. S., Anand, T. N. C. and Ravikrishna, R. V. (2011). High swirl-inducing piston bowls in small diesel engines for emission reduction. Applied Thermal Energy, 88, 2355-2367. https://doi.org/10.1016/j.apenergy.2010.12.068

Praveena, V. and Leenus Jesu Martin, M. (2017). A review on various after treatment techniques to reduce NOx emissions in a CI engine. Journal of the Energy Institute, 1743-9671.

Praveena, V., Aswin, N. S., Vishnu Balaji, R. and Srikrishna, S. (2018). Effect of combustion chamber geometries in biodiesel fuelled CI engine: A comprehensive review. 2nd International conference on Advances in Mechanical Engineering (ICAME 2018), IOP Publishing, IOP Conf. Series: Materials Science and Engineering 402(2018), 012104. https://doi.org/10.1088/1757-899X/402/1/012104

Puhan, S., Vedaraman, N., Ram, B. V. B., Sankaranarayanan, G. and Jeychandran, K. (2005). Mahua oil (Madhuca Indica seed oil) methyl ester as biodiesel-preparation and emission characteristics. Biomass Bioenergy, 28, 87-93. https:/ / doi.org/10.1016/j.biombioe.2004.06.002

Pyari, R., Salvador, F. J., Gimeno, J. and Zapata, L. D. (2008). Diesel nozzle geometry influence on spray liquidphase fuel penetration in evaporative conditions. Fuel, 87, 1165-76. https://doi.org/10.1016/j.fuel.2007.05.058

Ragit, S. S., Mohapatra, S. K. and Kundu, K. (2010). Performance and emission evaluation of a diesel engine fuelled with methyl ester of neem oil and filtered neem oil. Journal of Scientific and Industrial Research, 69, 62-66.

Raheman, H. and Ghadge, S. V. (2007). Performance of compression ignition engine with mahua (Madhuca indica) biodiesel. Fuel, 86, 2568-2573. https://doi.org/10.1016/j.fuel.2007.02.019

Raheman, H. and Phadatare, A. G. (2004). Diesel engine emissions and performance from blends of karanja methyl ester and diesel. Biomass and Bioenergy, 27, 393-397. https://doi.org/10.1016/j.biombioe.2004.03.002

Rajan, K. and Senthil Kumar, K. R. (2010). Performance and Emission Characteristics of Diesel Engine with Internal Jet Piston using Bio diesel. International Journal of Environmental Studies, 67(4), 556-567. https://doi.org/10.1080/00207233.2010.508252

Ramadhas, A. S., Jayaraj, S. and Muraleedharan, C. (2005). Characterization and effect of using rubber seed oil as fuel in the compression ignition engines. Renewable Energy, 30, 795-803. https://doi.org/10.1016/j.renene.2004.07.002

Ramadhas, A. S., Muraleedharan, C. and Jayaraj, S. (2005). Performance and emission evaluation of a diesel engine fuelled with methyl esters of rubber seed oil. Renewable Energy, 30, 1789-1800. https://doi.org/10.1016/j.renene.2005.01.009

Ramesh Bapu, B. R, Saravanakumar, L. and Durga Prasad, B. (2015). Effects of Combustion Chamber Geometry on Combustion Characteristics of a DI Diesel Engine Fuelled with Calophyllum Inophyllum Methyl Ester. Journal- Energy Institute, 90(1). https://doi.org/10.1016/j.joei.2015.10.004

Rao, T. V., Rao, G. P. and Reddy, K. H. C. (2008). Experimental investigation of Pongamia, jatropha and neem methyl esters as biodiesel on C.I. engine. Jordan Journal of Mechanical Industrial Engineering, 2, 117-22.

Ravichandran, A., Rajan, K., Rajaram Narayanan, M. and Senthil Kumar, K. R. (2016). Effect of piston bowl geometry on the performance of a diesel engine using Corn biodiesel and its diesel blends. International Journal of Chem Tech Research, 9(01), 105-112.

Ravindranath, N. H. and Balachandra, P. (2009). Sustainable bioenergy for India: Technical, economic and policy analysis. Energy, 34, 1003-1013. https://doi.org/10.1016/j.energy.2008.12.012 
Rosli, A. B. and Ismail Semin, A. R. (2008). Fuel injection pressure effect on performance of direct injection diesel engines based on experiment. American Journal of Applied Sciences, 5, 197- 202. https://doi.org/10.3844/ajassp.2008.197.202

Sakthisaravanasenthil, K., Senthilkumar, S. and Sivakumar, G. (2017). A study on effect of piston bowl shape on engine performance and emission characteristics of a diesel engine. In book: Bajpai, R. and Chandrasekhar, U. editors. Innovative design and development practices in aerospace and automotive engineering. Singapore: Springer, 579-88. https://doi.org/10.1007/978-981-10-1771-1_61

Sayin, C. and Gumus, M. (2011). Impact of compression ratio and injection parameters on the performance and emissions of a DI diesel engine fueled with biodiesel-blended diesel fuel. Applied Thermal Engineering, 31 3182-3188. https://doi.org/10.1016/j.applthermaleng.2011.05.044

Shrivastava, N., Varma, S. N. and Pandey, M. (2012). A Study on Reduction of Oxides of Nitrogen with Jatropha Oil Based Bio Diesel. International Journal of Renewable Energy Research, 2(3), 504-509.

Sun, Z. Y., Li, G. X. and Chen, C. (2015). Numerical investigation on effects of nozzle's Geometric parameters on the flow and the cavitation characteristics within injector's nozzle for a high-pressure common-rail DI diesel engine. Energy Conversion and Management, 89, 843-861. https://doi.org/10.1016/j.enconman.2014.10.047

Taufiq Suryantoro, M., Sugiarto, B. and Mulyadi, F. (2016). Growth and characterization of deposits in the combustion chamber of a diesel engine fuelled with B50 and Indonesian biodiesel fuel (IBF). Biofuel Research Journal, 3(4), Article 6, 521-527. https://doi.org/10.18331/BRJ2016.3.4.6

Xu, C., Abul Kalam, Md. And Cho, H. (2018). The Study on the Effect of the Piston Shapes through Biodiesel Mixture Combustion in Diesel Engine, ICAEER 2018. E3S Web of Conferences, 53, 03022. https://doi.org/10.1051/e3sconf/20185303022

Xue, J., Grift, T. E. and Hansen, A. C. (2011). Effect of biodiesel on engine performances and emissions. Renewable and Sustainable Energy Reviews, 15, 1098-1116. https://doi.org/10.1016/j.rser.2010.11.016

Yaliwal, V. S., Banapurmath, N. R., Tewari, P. G., Kundagol, S. I., Daboji, S. R. and Galveen, S. C. (2011). Production of renewable liquid fuels for diesel engine applications -a review. Journal of Selected Areas in Renewable and Sustainable Energy (JRSE), January Edition. 